\title{
sciendo
}

DOI 10.2478/sbe-2020-0047

SBE no. 15(3) 2020

\section{COMPARING THE IMPACT OF THE NET INCOME VERSUS THE COMPREHENSIVE INCOME OVER THE SHARE PRICE FOR COMPANIES LISTED ON THE BUCHAREST STOCK EXCHANGE}

\author{
POP IOANA \\ Lucian Blaga University of Sibiu, Romania
}

\begin{abstract}
:
As a consequence of adopting the IFRS in Romania, starting with 2012, for companies whose securities are admitted for trading on a regulated market, financial reporting demarches include ascertaining the comprehensive income in addition to the net income. The present paper aims at investigating how the share price evolves considering the level of the comprehensive income as compared to the reported net income, in a multiannual empirical study implying panel data analysis through Pooled OLS, Fixed Effects and Random Effects models processed through EViews. Furthermore, the informational and decisional utility of the two main forms of disclosed accounting results (the net income and of the comprehensive income) is examined through a sample of 57 notable companies listed on the Bucharest Stock Exchange. Admittedly, the empirical study findings substantiate the fact that both results categories are significantly associated with the evolution of the share price, rendering a heightened value relevance for the Romanian capital market investors. Moreover, the identified results indicate that from an investor standpoint, the comprehensive income does not bear a greater significance than the net income, the two having comparable impacts over the share price.
\end{abstract}

Key words: comprehensive income, net income, IFRS, Bucharest Stock Exchange, share price

\section{Introduction}

Admittedly, performance is an ever-current issue, extensively researched in both Romanian and foreign literature, by specialists in finance, management, auditing, accounting and evaluation. Broadly, performance expresses the favorable result of an action, being associated with success and triumph in a field. Exploring and understanding the multiple facets of the concept of financial performance, alongside with its generating and amplifying factors, is of major importance especially in the current international economic context.

Performance is a state of competitiveness of the company that ensures its sustainable presence on the market, an indicator of potential future results that appears as a result of reaching strategic objectives (Jianu, 2007), consequently creating the premises 
for a viable prospective approach. In order for a company to be efficient it needs to simultaneously be productive and effective. Moreover, performance is always the product of a comparison or reporting to the predetermined multidimensional objectives.

Certainly, accounting results are considered to be the first reliable measures for assessing company performance. Furthermore, they are intended to quantify post-factum the results of the company's activity. Therefore, we note that the accounting result is retrospective, past-oriented, measures the progress made during the financial year and is determined on a regular basis. We acknowledge that the objectivity of the result is impaired by the existence of options for the evaluation and presentation of the elements of financial reporting. However, well-established regulation can be the solution to mending the limitations of financial disclosures.

Out of the desire to mobilize a high or a sufficient level of financial resources, companies choose to trade their financial instruments on capital markets even beyond their national borders. In order to fulfill this desideratum, they must provide high-quality, complete, transparent, comparable, but especially accessible financial-accounting information, so as to facilitate the uniform and timely information of the users. In this context, nevertheless, capital market investors use decision-making reasoning related to the accounting results in order to substantiate investment decisions.

Driven by the need to adapt to the constantly evolving international economic environment, the European accounting authorities have chosen to comply with international reporting standards and go through the stages of harmonization. Moreover, the current reality shows us that international regulators are focusing their efforts on developing a common frame of reference based on clear and unique concepts, principles, accounting rules for all producers and users of accounting information.

We admit the fact that in Romania the change of focus in elaborating and disclosing financial reports, from the information needs of the state to the satisfaction of the investor's information needs, came as a recognition of the capital market's role in business growth. Overall, this process was carried out under the stringency of the European regulations, as normative changes were made in order to actively connect the national economy to the requirements generated by globalization dynamics.

Considering the continuous integration of international markets, we are of the opinion that the future of accounting normalization in Romania is closely linked to the evolutions manifested at European and international level. Companies quoted on the capital market have a higher certainty regarding the stability of the applicable accounting regulations, which is still utopian for small and medium-sized entities. For the latter, we identify the need for normalization considering the particularities of the national framework.

From whichever theoretical spectrum it would be approached, the importance of accounting results remains unchanged. The result is used in predicting future fundamental performance in investment decision-making, it constitutes an element of analysis of the company's development strategy, it lays a foundation of credibility with third parties and is a lever for assessing the management quality.

We identify a greater interest in detailing the elements that condition the level of accounting results, the most notable motivation being that they are the first measure of financial performance, the one based on which a diagnosis can be set, assess stock 
market performance can be evaluated or intrinsic values of business or traded securities can be identified adequately.

We also note the importance given by the IFRS optics to the freedom regarding the professional reasoning in the approach of efficient dissemination of information. We consider that starting from the indications of the international reference, based on a healthy professional reasoning, the usefulness and quality of financial reports can be amplified in order to improve the degree of satisfaction of the requirements imposed by investors, by disseminating additional, specific and adapted information, thus, facilitating the understanding of the global message disseminated.

We admit that the modern approach to the comprehensive result models the perspective on performance, highlighting exhaustively and taxonomically the occurred value changes, integrating those alterations generated by the business level with those resulting from the value changes of assets or liabilities. Consequently, the result becomes a reflection of the market value, exceeding the limits of the traditional approach based strictly on the specific dimensions and valences of the cost.

\section{Comprehensive income versus net income - current debates and literature review}

As a consequence of the frequent use of the accounting result as a measure of assessing company performance, accounting information users show an increased interest in how it is calculated, but also in the flows of revenue and expense that condition it (Gîrbină, Bunea, 2009). In this context, the statement of financial position proves to be insufficient, as it cannot provide complete information on the income and its formation, and the requirement to disseminate a dedicated profit or loss (P\&L) report becomes stringent.

The last decades have brought visible improvements to income statement reporting, first of all, especially with the appearance of FAS 130 of the FASB in the United States of America, with applicability from December $15^{\text {th }} 1997$. This rule was dedicated to outlining the comprehensive result and required the presentation of items directly recognized in equity, the publication of a single statement of comprehensive performance and the dissemination of an income statement or changes in equity alongside disclosing the transactions perfected with owners. This American approach is followed by other states such as the United Kingdom of Great Britain and Northern Ireland, New Zealand, Australia and Canada, jurisdictions that recognize the importance of the concept of the comprehensive income (or global result) and formalize normative steps to implement, impose and promote it. At the same time, the IASC revises IAS 1 by including the second statement on changes in equity, other than those arising from transactions with owners.

The total comprehensive income is the variation of equity generated by transactions and events that were not carried out with the owners in their capacity of owners (Gîrbină, Bunea, 2009). Therefore, we admit that the modern approach to the comprehensive result shapes the performance perspective, highlighting exhaustively and taxonomically the value changes occasioned and related to the period, integrating those generated by the business activity of the entity with those resulting from holding (losses or gains) with direct impact on the value of the assets or liabilities that describe the financial 
position of the company. Consequently, the result becomes a reflection of market value, exceeding the limits of a strictly cost - based approach.

Currently, the international accounting standards require the publication of a statement of comprehensive income and a statement of changes in equity (IAS 1). Admittedly, the two reports are complementary and indispensable to forming correct assessments regarding the global performance of a company and therefore the obligation to disseminate both reports is justified.

We subscribe to the view that building a true and fair view over the company comprehensive performance should not be left to arbitrariness, so as not to perpetuate or create significant risks in the financial communication process with significant repercussions on the business stability. Moreover, the delimitation of the operational level from the global (or comprehensive) one in shaping the result, leads to a greater detailing of the two levels, when the relevant information is completely and adequately disseminated. At the same time, we observe that this conceptual delimitation is neither random nor redundant, on the contrary it satisfies two complementary information requirements of the user, measuring the performance of the activity and quantifying the value creation for shareholders.

In order to adequately understand the informative value of the comprehensive income, it is important to comprehend how it is ascertained. Even though it stems from the net income, comprehensive income incorporates a series of other elements, as follows:

Net income (profit / loss)
\pm Other elements of the comprehensive income, consisting primarily of:
Changes in the revaluation surplus of fixed assets
\pm Actuarial gains / losses from pension and benefit plans
\pm Gains / losses from the conversion of operations abroad
\pm Gains / losses on the revaluation of financial assets for disposal
\pm Gains / losses on hedging
\pm Real estate revaluation gains / losses
\pm The portion of other comprehensive income of associates
- Income tax related to the aforementioned components
\pm Other elements of the comprehensive income
$=$ Total comprehensive income

Comparing the ways of determining the comprehensive income and the net income, we can identify a more generous informational content in favor of the first indicator. Moreover, the perspective of the international standards promotes the comprehensive result as a superior, more adequate measure of performance appreciation, especially for quoted companies.

Analyzing the literature, supported by empirical research, we identify a preference of investors for the net income, in developed capital markets. Therefore, the most numerous are the studies that establish a link between share price and the disclosed net income, but also an increased predictive value of the net income as compared to the comprehensive income. 
In an extensive study of listed companies in 16 European states, Goncharov and Hodgson (2011) identify a higher predictive value of the net result against the comprehensive one in stock price assessment, similar results to the research conducted by Jones and Smith (2011) on issuers from the USA and the one conducted by Kabir and Laswad (2011) by analyzing the results of New Zealand issuers in correlation with their stock market performance. To these studies is added the research of Brimble and Hudgson (2005) on the performance of Australian industry entities, which also identifies a correlation of the net result with the share price. We also mention the study conducted by Pronobis and Zulch (2010) focused on the predictive value of the result coordinates reported by the German entities, concluding a superior predictability of the net result corroborated with inconclusive values on the comprehensive income. More extensive research, including on listed companies in France, Germany, the United Kingdom, and the United States, conducted by Isido, O'Hanlon, and Young (2004) reveals a close link between PBR (price to book ratio) and disclosed net income, considering that the comprehensive income would not concentrate a higher informational content.

By contrast, some studies outline an increased utility of the comprehensive income compared to the net income. Kim (2017) identifies an increased attention of US investors to the comprehensive income and its increased relevance when reported using the two distinct situations (income statement and comprehensive income report), to the detriment of the integrated income statement and other comprehensive income.

Lin (2006), analyzing the results reported by British listed industrial entities, identifies a higher relevance of the comprehensive income in the forecast of the issuers' share price. Similarly, the conclusions of the study conducted by Kanagaretnam, Mathieu and Shehata (2009) identify a significant correlation of the comprehensive income reported by Canadian quoted companies with their stock market performance. Kubota, Suda and Takehara (2006) share the same assessment in a study of listed entities in Japan, followed by Biddle and Choi (2006) with Chambers, Linsmeier, Shakespeare and Sougiannis (2007) through independent studies on US listed companies.

Moreover, from the investor's perspective, Szychta and De la Rosa (2012) identify a cumulative value of the efforts to disseminate both forms of the result (net and comprehensive) of Polish companies listed on the WSE (Warsaw Stock Exchange). At the same time, Fernández and Arana (2010), starting from the study of the stock market performances of Spanish entities, characterize the comprehensive result as a more appropriate measure, connected to the realities of the capital market, which mediates more reliable and forward-looking forecasts, delineating it form the traditional model of the net result, which is dominated by the historical cost.

Consequently, we naturally ask ourselves whether additional efforts to report the comprehensive income, in all complexity of its coordinates are justified, regardless of the net income. Our belief is that any further dissemination of significant elements is relevant and timely, strengthening the attribute of transparency in investor communication. Moreover, the superior credibility generated by the connection to IFRS requirements and the associated long-term benefits outweigh the costs or efforts made in moving towards the comprehensive income. At the same time, we appreciate that understanding the employed measures of company accounting results (net versus comprehensive income) 
and their connection with the stock market performance, is fundamental in assisting viable investment decisions.

At the same time, we identify an additional utility and value attracted by the comparison of the two measures of performance (net versus global level), through the additional control provided, as the differences between the two coordinates should exist, but in essence the comprehensive income should not differ strongly from the net result or from the calculation based on cash flows, approaches based on concrete events and transactions, disconnected from the subjective side.

As argued above, the concept of comprehensive income is more comprehensive than the net income presented in the income statement because it considers supplementary elements attributable to the additional gain and loss coordinates. At the same time, starting from this reasoning, we admit that the comprehensive income is more and more used and preferred by investors and analysts. Moreover, this is the result of the convergence process started by the IASB and the FASB and has a correspondent in American accounting practice through the complete result.

\section{Research methodology}

Considering the above theoretical and empirical support, for the present study we decided to organize the primary database in a panel type structure based on data retrieved from the financial reports of companies quoted on the Bucharest Stock Exchange in a time spectrum of 6 years, between 2012-201. We add that starting with 2012 Romanian listed companies need to comply with the international accounting standards for their individual reports and by consequence they disclose comprehensive and net income statements. The panel is balanced (more precisely, it does not present missing information), consisting of 57 companies. The selected companies operate in industry, commerce and services. Additionally, we acknowledge that the selected listed companies are perceived as good examples of performance, business and stock market success. Furthermore, from the initial data range, consisting of 80 entities listed in the Standard and Premium categories of BSE, whose status was tradable at April $1^{\text {st }} 2018$, there were eliminated the companies which did not disclose the necessary data, that did not have trade continuity in the selected time frame or operated in the financial and banking sector.

The linear models estimated for research have been designed to avoid situations regarding the impossibility of performing the necessary statistical calculations and contain the following variables:

- the first model analyzes the connection between the evolution of share price and earnings per share:

the share price was set as the dependent variable (abbreviated $\mathrm{P}$ );

the independent variable was set as earnings per share, determined based on the net income (noted by EPS);

- the second analyzes the link between the evolution of share price and comprehensive income per share:

the share price was set as the dependent variable (abbreviated $\mathrm{P}$ ); 
independent variable: comprehensive income per share (to avoid confusion in terms of ratings CIPS);

We admit that, most of the times, in the cases where analyzed data is organized under the panel typology (table, list), with more than one observation per company, the observations included in the database prove not to be completely independent. By consequence, the applied econometric models are specific to panel type data and follow the evolution of the sample regarding the predetermined variables as well as their variations proven in the selected time frame. Moreover, the requirement to meet the stationary criteria of the variables must precede the econometric modeling approaches. In this regard, we applied specific stationarity tests through the EViews statistical processing software.

The econometric models (of theoretical basis) specific to panel type data analysis, which will be employed and estimated in the present paper, are as follows:

- the Pooled OLS model is a linear model estimated by the least squares' method, in the view of which the individual effects that could exist at the data level are ignored, assuming that all companies would have the same characteristics:

$$
y i t=x i t \beta+w i y+(\eta i+\epsilon i j)
$$

- the Fixed Effects (FE, Within Groups) model eliminates the average of the period from each independent variable at the level of each company in the panel, in other words there is no correlation between the independent variables and the error elements, thus eliminating the influence of unnoticed factors at the level data and, at the same time, constant variables are removed from the model;

- the Random Effects (RE) model considers the influence of the differences between the entities in the panel on the dependent variable, by introducing an individual constant specific to each entity, which incorporates these differences, and the exogeneity of the model is guaranteed.

The final goal of all the performed analyses is to estimate the most appropriate econometric model, applicable to centralized primary data, organized in the form of a panel, which expresses in a relevant way the quantitative link between the variables followed in the multicriteria temporal analysis.

The scientific methodology in the field of panel data analysis recommends estimating all three econometric models and choosing the most appropriate model. The issue of selecting the most appropriate model must be solved and the solution is indicated by the Hausman Test. The quality of FE model estimators depends on the extent to which the independent variables vary over time. Consequently, the FE model is most appropriate when we are interested in highlighting the influence of the time factor on variables, between the entities in the panel. If there are good reasons to consider that there are concrete differences between the characteristics of the entities in the panel, then the most appropriate model for estimating the relationships between the dependent variable and the independent ones is the RE model.

The final decision shall properly duly substantiated on the basis of a simple majority of the results of the tests applied. The assumptions underlying any stationarity test 
are unchanged, we always want to reject the null hypothesis $\left(\mathrm{H}_{0}\right)$ and accept the alternative $\left(\mathrm{H}_{1}\right)$, which requires the value Prob. at most $4.99 \%$, with the significance of targeting the error level below the maximum agreed level of $5 \%$.

As can be observed in table no. 1, for the dependent variable, the share price, the Prob value. is higher than $5 \%$ for all 3 stationarity tests applied. The null hypothesis of nonstationarity cannot be rejected. We notice that the variable share price is non-stationary at the basic level and, consequently, its logarithm is required. We mention that the variable becomes stationary through the logarithm operation (LNP) according to the subsequent table. Among the variables included in the analysis, the independent variables, EPS and CIPS, were detected as stationary around a null constant, results confirmed based on most of the test results applied.

\section{Table no. 1. Stationarity tests for price variable P (Level, None)}

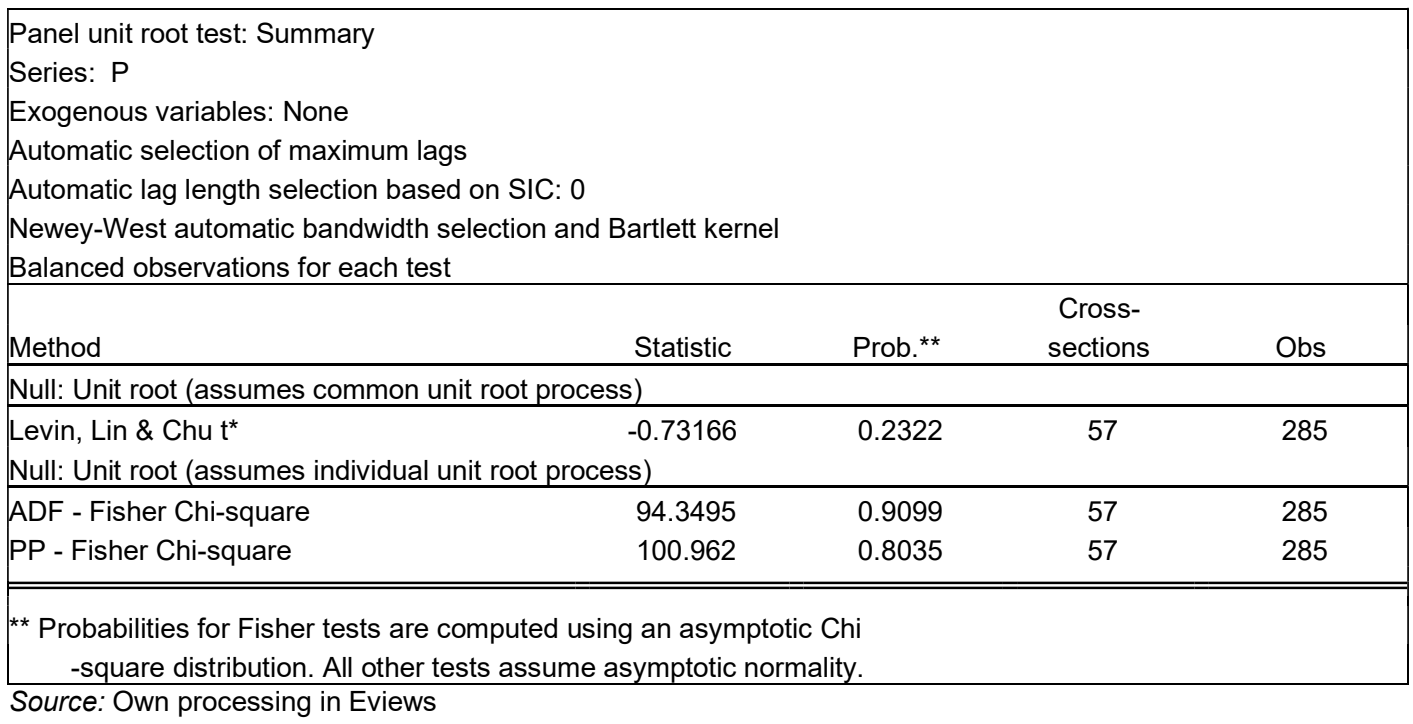

The subsequent matrix of correlation coefficients between the dependent variable and the independent variables confirms the existence of a statistically significant correlation link between the share price and the independent variable, EPS and CIPS. This correlation is shown through the subsequent table no. 2 .

Table no. 2. Matrix of correlation coefficients between stationary variables

\begin{tabular}{|c|c|c|c|}
\hline \multicolumn{4}{|c|}{$\begin{array}{l}\text { Covariance Analysis: Ordinary } \\
\text { Included observations: } 342\end{array}$} \\
\hline \multicolumn{4}{|c|}{ Correlation } \\
\hline Probability & LNP & EPS & CIPS \\
\hline \multirow[t]{2}{*}{ LNP } & 1.000000 & & \\
\hline & ---- & & \\
\hline \multirow[t]{2}{*}{ EPS } & 0.115906 & 1.000000 & \\
\hline & 0.0321 & - & \\
\hline \multirow[t]{2}{*}{ CIPS } & 0.120552 & 0.999710 & 1.000000 \\
\hline & 0.0258 & 0.0000 & ---- \\
\hline
\end{tabular}


Based on previous calculations, we can identify that the effect on the share price is a positive one for both independent variables, more precisely when these performance indicators increase (EPS and CIPS), the share price is also expected to increase, the correlation links being of a direct nature. We also need to mention the fact that the detected connection is of a low intensity.

\section{The impact of earnings per share on the share price for companies listed on the Bucharest Stock Exchange - results and discussions}

The Pooled OLS model applied to the association of LNP-EPS (LNP being the logarithmical form of $P$, which we employed in order to stabilize the variable) variables estimated in table no. 1. has the following characteristics from a statistical perspective: it is a valid global model, in terms of statistical fundamentals, Prob (F-statistical) being lower than the maximum acceptable level of error meaning $5 \%(0.032124)$ has correlated estimation errors (Durbin- Watson undertaking a value of 0.052935). Moreover, it explains in proportion of $1.3 \%$ the variation of the share price in the sample. From this point of view the model must be improved by adding other independent variables. Furthermore, it contains statistically significant variables (EPS and constant) in terms of estimated coefficients, by consequence the hypothesis of insignificance being rejected (Prob. lower than the relevance quota of $5 \%$ ).

However, this initially estimated model cannot be considered the reference model, considering the fact that the individual effects that could exist at the data level are ignored, as if all companies had the same characteristics. Admittedly, formulated in a mathematical form, the connection between the two variables, through the stringencies of the Pooled OLS methodology is given by equation no. 2. :

$$
L N P=0.015178^{\star} E P S-0.228532
$$

Continuing the process of estimating the econometric models, according to table no. 3. The Fixed Effects regression equation between LNP and EPS has the following features:

- explains in proportion of $96.7 \%$ the variation of the share price in the panel;

- from the perspective of the Prob result (F-Statistic) is a representative global model (the null hypothesis of the test is rejected at a significance threshold of $0.1 \%)$;

- estimation errors are correlated (Durbin-Watson statistics are found at the level of 0.952795 below the value 2 , considered to be the reference);

- the coefficient of the constant and that of the independent variable are statistically significant (Prob. Values being below the maximum agreed quota of $5 \%$ );

- the mathematical form of the model is materialized in equation no. 3., as follows:

$$
L N P=0.00346763967541^{\star} E P S-0.226081619203+[C X=F]
$$


Table no. 3. Fixed Effects model, on stationary LNP and EPS variables

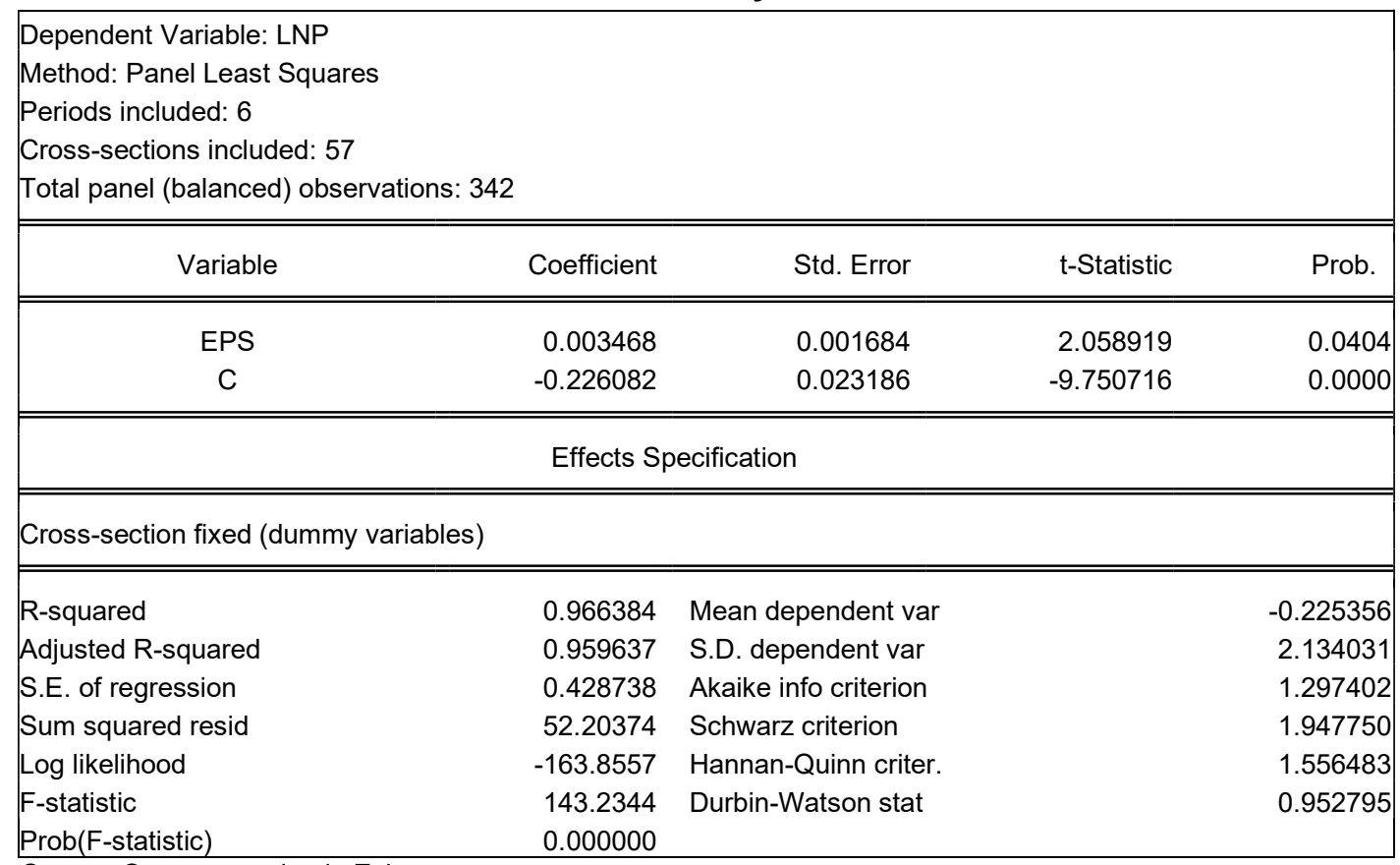

Source: Own processing in Eviews

The third basic model in panel econometric modeling, the Random Effects model, explains $1.31 \%$ of the share price change, but has correlated estimation errors (the DurbinWatson test recorded a value of 0.795461 ), as well as the coefficient statistically insignificant constant (Prob. of 0.4158 exceeding the maximum agreed level of $5 \%$ ). Accordingly, this model is not correctly constructed in terms of component variables. Consequently, we proceed to the re-estimation of the model in the hypothesis in which this is the most indicated way for modeling the connection, through the Hausman test.

The standard hypotheses tested in table no. 4 , in the case of the mentioned test are the following:

$\mathrm{H}_{0}$ : The RE model is the most appropriate model for estimating the econometric model.

$\mathrm{H}_{1}$ : The FE model is the most appropriate model for estimating the econometric model.

Table no. 4. Hausman test applied on the Random Effects model

\begin{tabular}{|c|c|c|c|}
\hline \multicolumn{4}{|l|}{$\begin{array}{l}\text { Correlated Random Effects - Hausman Test } \\
\text { Equation: Untitled } \\
\text { Test cross-section random effects }\end{array}$} \\
\hline Test Summary & Chi-Sq. Statistic & Chi-Sq. d.f. & Prob. \\
\hline Cross-section random & 1.653208 & 1 & 0.1985 \\
\hline \multicolumn{4}{|l|}{ Cross-section random effects test comparisons: } \\
\hline Variable & Random & Var(Diff.) & Prob. \\
\hline 0.003468 & 0.003582 & 0.000000 & 0.1985 \\
\hline
\end{tabular}

Source: Own processing in Eviews 
As we can observe, at a significance threshold of $1 \%$, the null hypothesis cannot be rejected. The most appropriate model for this combination of variables is the Random Effects model (table no. 5).

\section{Table no. 5. Random Effects model for LNP-EPS connection}

\begin{tabular}{|c|c|c|c|c|}
\hline \multicolumn{5}{|c|}{$\begin{array}{l}\text { Dependent Variable: LNP } \\
\text { Method: Panel EGLS (Cross-section random effects) } \\
\text { Periods included: } 6 \\
\text { Cross-sections included: } 57 \\
\text { Total panel (balanced) observations: } 342 \\
\text { Swamy and Arora estimator of component variances } \\
\text { White period standard errors \& covariance (no d.f. correction) }\end{array}$} \\
\hline Variable & Coefficient & Std. Error & t-Statistic & Prob. \\
\hline $\begin{array}{c}\text { EPS } \\
\text { C }\end{array}$ & $\begin{array}{r}0.003551 \\
-0.226099\end{array}$ & $\begin{array}{l}0.000810 \\
0.022168\end{array}$ & $\begin{array}{r}4.385150 \\
-10.19952\end{array}$ & $\begin{array}{l}0.0000 \\
0.0000\end{array}$ \\
\hline \multicolumn{5}{|c|}{ Effects Specification } \\
\hline $\begin{array}{l}\text { Cross-section random } \\
\text { Period fixed (dummy variables) } \\
\text { Idiosyncratic random }\end{array}$ & & & 2.088439 & 0.9626 \\
\hline \multicolumn{5}{|c|}{ Weighted Statistics } \\
\hline $\begin{array}{l}\text { R-squared } \\
\text { Adjusted R-squared } \\
\text { S.E. of regression } \\
\text { F-statistic } \\
\text { Prob(F-statistic) }\end{array}$ & $\begin{array}{l}0.092606 \\
0.076354 \\
0.411857 \\
5.698160 \\
0.000012\end{array}$ & $\begin{array}{l}\text { Mean dependent var } \\
\text { S.D. dependent var } \\
\text { Sum squared resid } \\
\text { Durbin-Watson stat }\end{array}$ & & $\begin{array}{r}-0.225356 \\
0.428542 \\
56.82476 \\
0.842524\end{array}$ \\
\hline \multicolumn{5}{|c|}{ Unweighted Statistics } \\
\hline $\begin{array}{l}\text { R-squared } \\
\text { Sum squared resid }\end{array}$ & $\begin{array}{l}0.008751 \\
1539.354\end{array}$ & $\begin{array}{l}\text { Mean dependent var } \\
\text { Durbin-Watson stat }\end{array}$ & & $\begin{array}{r}-0.225356 \\
0.031101\end{array}$ \\
\hline
\end{tabular}

Source: Own processing in Eviews

In order to re-estimate the model, the constant should be removed. Given the small number of observation periods, we will re-estimate the econometric model by fixing the number of time periods, we will set the covariant matrix of White errors (for the correction of heteroskedasticity of errors) and the Random Effects specification at entity level. Therefore, the mathematical form of the model is established by the regression equation no. 4 , as follows:

$$
L N P=0.0035508100809 * E P S-0.226099020528+[C X=R, P E R=F](4)
$$

The model revised by the previous table noted 4 . we consider that it is a valid global model, from the point of view of Prob (F-statistic) statistics, which takes a value of 0.000012 below the maximum agreed quota of $5 \%$, has correlated estimation errors 
(Durbin -Watson being 0.842524 ), explains in proportion of $9.3 \%$ the variation of the share price in the sample, and from this point of view we think that the model needs to be improved by adding other independent variables. At the same time, the model consists of both statistically significant variables (EPS and constant) in terms of the coefficients estimated by the included intermediate calculations.

\section{The impact of comprehensive income per share on the share price for companies listed on the Bucharest Stock Exchange - results and discussions}

Regarding the estimation model consisting of the variable LNP (dependent variable, natural logarithm - In - applied to the price per share in order to stationary the variable to be used in the econometric modeling process) and CIPS (independent variable, comprehensive income per share, which was identified be stationary, accordingly, its logarithm not being required), the stages of its construction and validation coincide with those covered in the previous section. The results of the stationarity test indicate the rejection of the null hypothesis and the acceptance of the alternative, at a significance threshold of $5 \%$, so the dependent variable is found to be stationary at the data level.

Pooled OLS type econometric model, shown in table no. 6., proves to be a valid global model (Prob (F-statistic) with the value of 0.025789 being at a lower level than the maximum agreed of 0.05 ), has correlated estimation errors (Durbin-Watson test value of $0.054895)$, explains in proportion of $1.45 \%$ the variation of the share price, consequently being necessary additional independent variables for explaining the model at a higher statistical level.

\section{Table no. 6. Pooled OLS model, on stationary variables LNP and CIPS}

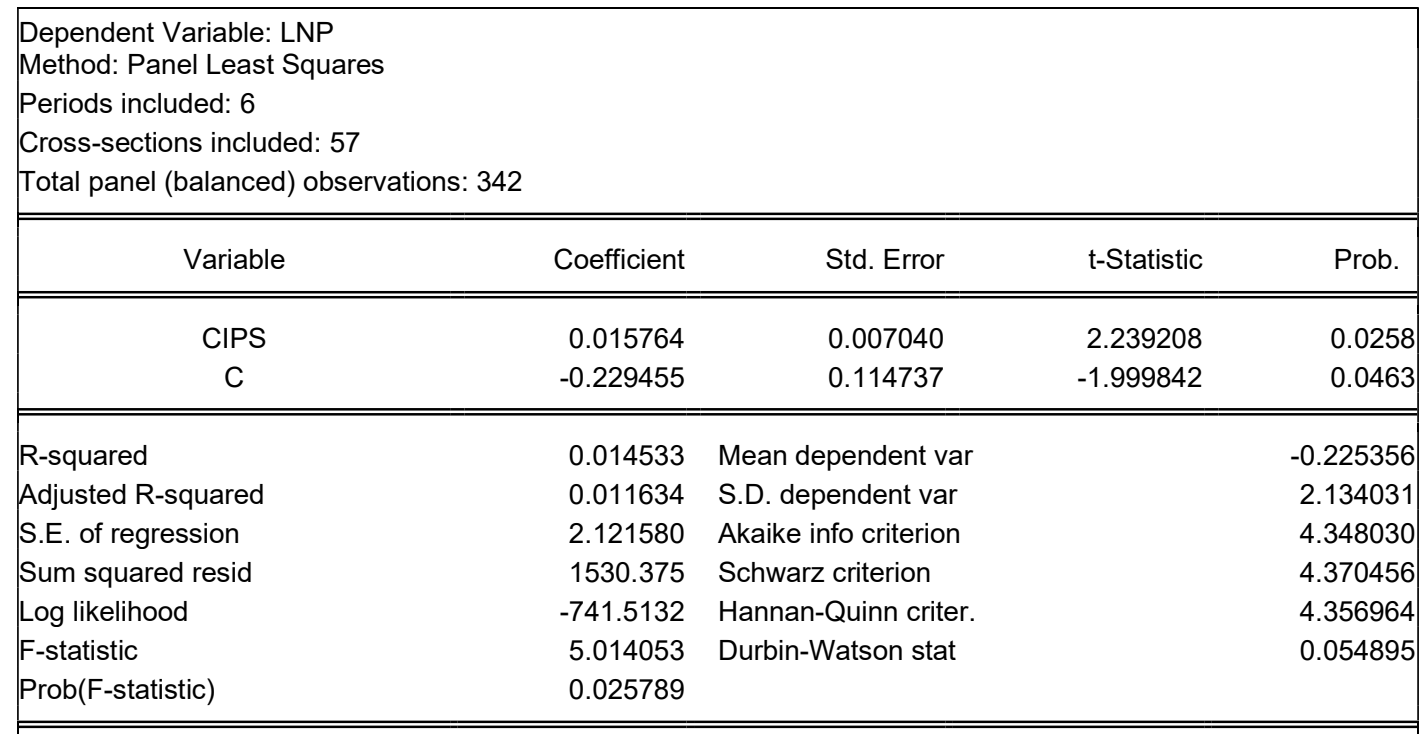

Source: Own processing in Eviews 
Fixed Effects model, shown in table no. 7., has the coefficient of the statistically significant independent variable (at a significance threshold of $5 \%$ ), as well as the constant.

Table no. 7. Fixed Effects model, on stationary variables LNP and CIPS

\begin{tabular}{|c|c|c|c|c|}
\hline \multicolumn{5}{|c|}{$\begin{array}{l}\text { Dependent Variable: LNP } \\
\text { Method: Panel Least Squares } \\
\text { Periods included: } 6 \\
\text { Cross-sections included: } 57 \\
\text { Total panel (balanced) observations: } 342\end{array}$} \\
\hline Variable & Coefficient & Std. Error & t-Statistic & Prob. \\
\hline CIPS & 0.003460 & 0.001683 & 2.055489 & 0.0407 \\
\hline $\mathrm{C}$ & -0.226256 & 0.023188 & -9.757376 & 0.0000 \\
\hline \multicolumn{5}{|c|}{ Effects Specification } \\
\hline \multicolumn{5}{|c|}{ Cross-section fixed (dummy variables) } \\
\hline R-squared & 0.966382 & Mean dependent var & & -0.225356 \\
\hline Adjusted R-squared & 0.959635 & S.D. dependent var & & 2.134031 \\
\hline S.E. of regression & 0.428748 & Akaike info criterion & & 1.297451 \\
\hline Sum squared resid & 52.20630 & Schwarz criterion & & 1.947799 \\
\hline Log likelihood & -163.8641 & Hannan-Quinn criter. & & 1.556532 \\
\hline F-statistic & 143.2272 & Durbin-Watson stat & & 0.952850 \\
\hline Prob(F-statistic) & 0.000000 & & & \\
\hline
\end{tabular}

Source: Own processing in Eviews

Moreover, starting from table no. 7., we also identify that the model explains in a very high proportion, more precisely of $96.63 \%$, the variation of the dependent variable, presents correlated errors (the value of the Durbin-Watson statistic being 0.952850 ), but is considered to be globally representative (Prob. F-Statistic being zero, more precisely below the maximum theoretical share of $5 \%$ ).

\section{Table no. 8. Hausman test applied on the Random Effects model}

\begin{tabular}{|c|c|c|c|c|}
\hline \multicolumn{5}{|c|}{$\begin{array}{l}\text { Correlated Random Effects - Hausman Test } \\
\text { Equation: RE2_0 } \\
\text { Test cross-section random effects }\end{array}$} \\
\hline Test Summary & & Chi-Sq. Statistic & Chi-Sq. d.f. & Prob. \\
\hline Cross-section random & & 1.828233 & 1 & 0.1763 \\
\hline \multicolumn{5}{|c|}{ Cross-section random effects test comparisons: } \\
\hline Variable & Fixed & Random & Var(Diff.) & Prob. \\
\hline CIPS & 0.003460 & 0.003580 & 0.000000 & 0.1763 \\
\hline
\end{tabular}

Source: Own processing in Eviews

The third model analyzed is shown in table no. 8. and represents the Random Effects model, explains in proportion of $1.31 \%$ of the variation of the dependent variable, 
has correlated estimation errors, the coefficient of the statistically insignificant constant. The constant cannot be removed (technically speaking), so this model cannot be validated in its current form and will be re-estimated.

As we can conclude based on the previous table, at a significance threshold of $1 \%$, the null hypothesis of the Hausman test cannot be rejected (Prob. Value $=0.1763>$ $5 \%$ ). The most suitable model for this combination of variables is the Random Effects model. At the same time, in order to be validated, this last model will be re-estimated by table no. 9.

\section{Table no. 9. The re-estimated Random Effects model for LNP-EPS variables}

\begin{tabular}{|c|c|c|c|c|}
\hline \multicolumn{5}{|c|}{$\begin{array}{l}\text { Dependent Variable: LNP } \\
\text { Method: Panel EGLS (Cross-section random effects) } \\
\text { Periods included: } 6 \\
\text { Cross-sections included: } 57 \\
\text { Total panel (balanced) observations: } 342 \\
\text { Swamy and Arora estimator of component variances } \\
\text { White period standard errors \& covariance (no d.f. correction) }\end{array}$} \\
\hline Variable & Coefficient & Std. Error & t-Statistic & Prob. \\
\hline $\begin{array}{l}\text { CIPS } \\
\text { C }\end{array}$ & $\begin{array}{r}0.003549 \\
-0.226279\end{array}$ & $\begin{array}{l}0.000809 \\
0.022199\end{array}$ & $\begin{array}{r}4.389199 \\
-10.19307\end{array}$ & $\begin{array}{l}0.0000 \\
0.0000\end{array}$ \\
\hline \multicolumn{5}{|c|}{ Effects Specification } \\
\hline $\begin{array}{l}\text { Cross-section random } \\
\text { Period fixed (dummy variables) } \\
\text { Idiosyncratic random }\end{array}$ & & & 2.084924 & 0.9625 \\
\hline \multicolumn{5}{|c|}{ Weighted Statistics } \\
\hline $\begin{array}{l}\text { R-squared } \\
\text { Adjusted R-squared } \\
\text { S.E. of regression } \\
\text { F-statistic } \\
\text { Prob(F-statistic) }\end{array}$ & $\begin{array}{l}0.092563 \\
0.076310 \\
0.411975 \\
5.695252 \\
0.000012\end{array}$ & $\begin{array}{l}\text { Mean dependent var } \\
\text { S.D. dependent var } \\
\text { Sum squared resid } \\
\text { Durbin-Watson stat }\end{array}$ & & $\begin{array}{r}-0.225356 \\
0.428654 \\
56.85722 \\
0.842199\end{array}$ \\
\hline \multicolumn{5}{|c|}{ Unweighted Statistics } \\
\hline $\begin{array}{l}\text { R-squared } \\
\text { Sum squared resid }\end{array}$ & $\begin{array}{l}0.009008 \\
1538.955\end{array}$ & $\begin{array}{l}\text { Mean dependent var } \\
\text { Durbin-Watson stat }\end{array}$ & & $\begin{array}{r}-0.225356 \\
0.031115\end{array}$ \\
\hline
\end{tabular}

Source: Own processing in Eviews

The Random Effects model was re-estimated by including the White-type error covariance matrix (for error heteroskedasticity correction), the entity-level Random Effects specification, and the Fixed period. The final mathematical form of the model is given by the regression equation no. 5. as follows:

$$
L N P=0.00354946384317^{*} C I P S-0.226278992943+[C X=R, P E R=F]
$$


The re-estimated Random Effects model through table no. 9. explains in proportion of $9.26 \%$ the variation of the dependent variable, presents correlated errors (DurbinWatson stat $=0.842199$ ), is globally representative (Prob. F-Statistic $=0.000012<5 \%$ ), has all the coefficients of the variables included in the statistically significant model (at a significance threshold of $5 \%$ ).

\section{Conclusions, research limitations and future research directions}

Two relevant econometric models of the Random Effects type were identified, models consisting of a dependent variable and an independent one, which link the share price (dependent variable) to the earnings per share (EPS), respectively to the comprehensive earnings per share (abbreviated CIPS). We mention that the data on their basis included the maximum number of entities listed without interruptions (suspensions) at the Bucharest Stock Exchange within the Standard and Premium categories during 2012-2017, which disseminated all the information relevant to the studies, namely 57 out of 80 initial sample and did not include the financial and banking sector. The primary data were structured in a panel type database (table, list) in which the companies are tracked in terms of evolution over time, being considered in their individuality and not being mathematically homogenized.

The estimated values of the coefficients in both econometric models show that the two independent variables in each model are extremely similar, explaining the same phenomenon, which leads to approximately identical values of the coefficients in the two models. This reveals to us that it is, in fact, sufficient to estimate a single model with either of the two proposed independent variables (earnings per share or comprehensive income per share). We admit that this was to be expected given that the comprehensive income is determined based on the net income, additionally incorporating a set of elements recognized directly in equity. Confirming the validity of the two estimated econometric models substantiates the existence of a quantitative link between the stock market evolution of the panel data companies in terms of share price and earnings per share (ascertained both on the net income and comprehensive income).

We cannot state that from the investor's perspective the net income is more valuable than the comprehensive one, as the supporting calculations, which implied econometric models performed through the EViews software, argued the extremely similar information value relevance in terms of correlation and evolutionary determination over the share trading price.

However, we admit that the practice and literature support specialized indicators and rates stemming from the net income, to the detriment of the comprehensive income, and an explanation in this sense would be the primacy of the operational level in the desideratum of company sustainability and profitability. Consequently, we could state that the elements incorporated in the comprehensive income, do not intrinsically condition the share price evolution but do condition the performance itself at both operational and overall activity levels.

Furthermore, the belief is that any further dissemination of significant elements is relevant and timely, strengthening the attribute of transparency in investor communication. 
Moreover, the superior credibility generated by the connection to IFRS requirements and the associated long-term benefits outweigh the costs or efforts made in moving towards the comprehensive income. At the same time, we appreciate that understanding the employed measures of company accounting results (net versus comprehensive income) and their connection with the stock market performance, is fundamental in devising viable investment decisions.

The limitations of the study are generated by the relatively small sample size, limited time frame (of six years) and from devising models based on one independent and one dependent variable in order to test the established hypotheses. Additionally, future research should aim at lower these limitations, as well as to extend the analyses on other capital markets, as well as devising models which possess a higher explanatory or predictive value.

\section{References}

Biddle, G.C., Choi, J-H. (2006). Is Comprehensive Income Useful? Journal of Contemporary Accounting \& Economics. 2 (1), p. 1-32;

Brimble, M., Hodgson, A. (2005). The Value Relevance of Comprehensive Income Components for Industrial Firms. Working Paper Amsterdam Business School;

Chambers, D., Linsmeier, T. J., Shakespeare, C., Sougiannis, T. (2007). An evaluation of SFAS No. 130 comprehensive income. Review of Accounting Studies. 12, 4, p. 557-593;

Fernández, F. S., Arana, M. M. C. (2010). Effects of comprehensive income on ROE in a context of crisis: Empirical evidence for IBEX-35 listed companies (2004-2008). International Business \& Economics Research Journal, 9(1), p. 117-128;

Gîrbină, M.M., Bunea, Ş. (2009). Sinteze, studii de caz şi teste grilă privind aplicarea IAS (revizuite) - IFRS. Volumul I, Ediţia a IV-a revizuită, Bucureşti: Editura CECCAR;

Goncharov, I., Hodgson, A. (2011). Measuring and Reporting Income in Europe. The Journal of International Accounting Research, 10, 1:27-60;

Isidro, H, O'Hanlon, J., Young, S. (2004). Dirty surplus accounting flows: international evidence. Accounting and Business Research. 34, 4: p. 383-410;

Jianu, I. (2007). Evaluarea, prezentarea şi analiza performanţei întreprinderii. O abordare din prisma Standardelor Internaţionale de Raportare Financiare. Bucureşti: Editura CECCAR;

Jones, D.A., Smith, K.J. (2011). Comparing the Value Relevance, Predictive Value, and Persistence of Other Comprehensive Income and Special Items. The Accounting Review, 86, 6, p. 20472073;

Kabir, M.H. Laswad, F. (2011). Properties of net income and total comprehensive income: New Zealand evidence. Accounting Research Journal. 24, 3, p. 268 - 289;

Kanagaretnam, K., Mathieu, R., Shehata, M. (2009). Usefulness of comprehensive income reporting in Canada. Journal of Accounting Public Policy, 28, p. 349-365;

Kim, J. H. (2017). Value Relevance of Other Comprehensive Income after Accounting Standards Update 2011-05. Academy of Accounting and Financial Studies Journal. 21(3), p. 1-13;

Kubota, K., Suda, K., Takehara, H. (2006). Information Content of Other Comprehensive Income and Net Income: Evidence for Japanese Firms. Asia-Pacific Journal of Accounting \& Economics. 18, 2, p.145-168;

Lin, S. (2006). Testing the Information Set Perspective of UK Financial Reporting Standard $N^{\circ} 3$ : Reporting Financial Performance. Journal of Business, Finance and Auditing. 33, 7-8, p. 1110-1141; 
Pronobis, P., Zulch, H. (2010). The Predictive Power of Comprehensive Income and its Individual Components Under IFRS. Working Paper, Leipzig School of Management;

Szychta, A., De la Rosa, D. (2012). Comprehensive income presentation under IAS 1: the reporting practices of the largest companies listed on the Warsaw Stock Exchange. Zeszyty Teoretyczne Rachunkowości. 68 (124), p. 121-145. 